\title{
Diagenetic History of the Chuping Limestone at Bukit Tungku Lembu, Perlis, Malaysia
}

(Sejarah Diagenesis Batu Kapur Chuping di Bukit Tungku Lembu, Perlis, Malaysia)

\author{
NoOrhashima Binti Adenan, CHE AzIZ Ali* \& KAMAl Roslan MoHAmed
}

\begin{abstract}
The Early Permian to Late Triassic limestone of Chuping Formation in Bukit Tungku Lembu consists of six microfacies and exhibits various types of diagenetic products, reflecting it's complicated diagenetic history. Out of 89 samples collected for petrographic studies, six major microfacies have been identified, namely brecciated limestone, dolomites, mudstones, wackestones, packstones and grainstones. Four major diagenetic processes comprising micritization, cementation, compaction and dolomitization have also been identified. Micritization occurs as the first phase diagenesis after the sediments were deposited on the sea floor, followed by cementation in the marine environment and also in meteoric environments when the shallow marine carbonate at some points in time was subjected to subaerial exposure. Early burial were indicated by fractures and deformation as well as destruction of grains whole structure. Increasing pressure during deeper burial has produced dissolution seams and stylolites. Dolomitization also occurred in the deeper burial environments.
\end{abstract}

Keywords: Chuping limestone; diagenesis; geochemistry; microfacies

\section{ABSTRAK}

Batu Kapur Chuping berusia Perm Awal hingga Trias Akhir di Bukit Tungku Lembu terdiri daripada enam mikrofasies dan memperlihatkan berbagai jenis hasil diagenesis, menggambarkan keragaman sejarahnya. Daripada 89 sampel yang dikutip untuk kajian petrografi, telah dikenal pasti enam mikrofasies iaitu batu kapur terbreksi, dolomit, batu lumpur, batu wak, batu padat dan batu butir. Empat proses diagenesis utama juga telah dikenal pasti seperti pemikritan, penyimenan, pemadatan dan pendolomitan. Pemikritan berlaku pada tahap awal diagenesis selepas sedimen dimendapkan di dasar laut, diikuti oleh penyimenan di sekitaran marin dan juga meteorik apabila sedimen pada suatu ketika terdedah kepada atmosfera. Penimbusan awal ditandai dengan peretakan dan canggaan serta pemusnahan keseluruhan butiran. Peningkatan tekanan semasa penimbusan menghasilkan pelarutan tekanan dan stilolit. Pendolomitan juga berlaku dalam sekitaran penimbusan dalam.

Kata kunci: Batu kapur Chuping; diagenesis; geokimia; mikrofasies

\section{INTRODUCTION}

Diagenesis refers to the sum of physical and chemical processes that transforms soft sediment into hard solid rock. The processes normally take place after sediment deposition to bind sediments together and become more stable (Wayne 2008). The process includes stages involving stabilization of carbonate mineral through dissolution of skeletal or any carbonate material to cementation and neomorphism, recrystallization and dolomitization (Flugel 2004) which could take place in any of the major diagenetic environments (Moore 1989).

Diagenesis is a process that takes place out of sight and out of mind since it occurs mostly when sediments are buried deeper in the subsurface. Even arguments and discussions are still being been made on how carbonate sediments become hard rock when there is no evidence of cements or cement crystals are found in the rocks. It is even more intriguing when considering how the porosity of deposited carbonate sediments had been reduced from normally $40-70 \%$ to less than $5 \%$ in carbonate rocks (Bathurst 1971) without any sign and evidence of compaction. Many researchers have suggested that it was due to cementation. However, the vast amount of cements needed to binds the sediments together need to be answered and most geologists have agreed that dissolution and reprecipitation of the carbonate materials could be the most plausible answer.

Cements are produced by re-precipitation from dissolution of carbonate skeletal materials or from replacement of metastable minerals such as aragonite and Mg-high calcite by more stable calcite cement (Bathurst 1971). Castanier et al. (1999) suggested that precipitation may also occur through carbonatogenous bacterial mediation. Precipitation of cements depends on factors such as chemistry of pore water, mineralogy and crystal chemistry, dissolution and precipitation rates, grain size, 
fluid movement and reactions with organic matters (Flugel 2004). Hence, different cement types will be produced in different diagenetic environments from which they are distinguished by their characteristic crystal habits and geochemical components (Tucker \& Wright 1990).

This paper is to document the different diagenetic and products that were produced by different diagenetic processes in different diagenetic environments experienced by the Chuping Limestone in Bukit Tungku Lembu area. Their characteristic and diagenetic environments will be discussed and finally its paradiagenetic sequence will be established.

\section{GEOLOGICAL SETTING}

This limestone in the study area was first described by Jones (1962) and named after Bukit Chuping in Beseri. The formation is well exposed in both Perlis and Langkawi (Gobbett 1973). In Langkawi, the limestone was found overlying the Devonian-Carboniferous clastic rocks of Singa Formation in Pulau Singa Kecil, Pulau Singa Besar, Pulau Jong and Pulau Jerkom (Jones 1981). However, in Perlis it forms a series of karst hills aligned in two parallel belts in North-South direction stretching from Southern Thailand where the limestone is known as Ratburi Limestone (Fontaine et al. 1994) until Beseri area (Azimah 1998). The limestone is generally massive and unfossiliferous except at the basal part where it consists of well-bedded dark limestone with chert nodules and abundant fossils (Gobbett 1973). The age of the limestone is estimated as Early Permian to Late Triassic by Kobayashi and Tamura (1968) as shown by the presence of fossils includes Marginifera sp. and Hamletella sp., Bellerophon sp., Euomphalus sp., Composita sp. (Gobbett 1973) and Sinopora dendroides. Fontaine et al. (1994) recorded the presence of Hemigordiopsids sp., Sphairionia sp. and Lophophyllidium sp. at Bukit Wang Pisang and Tubiphytes sp., Globivalvulin sp., Pachyphloia sp., Langella sp., Lasiodiscus sp. , Nodosariids, Pseudovermiporella nipponica, rare bryozoans, Sinopora asiatica (Fontaine et al. 1988) at Bukit Merah. These data suggest that the Chuping Limestone was deposited on a sheltered shelf away from shore line meanwhile isotopic data obtained by Rao (1988) suggested a cool temperate shallow marine setting.

\section{STUdy AREA AND METHODOLOGY}

A detailed field study was carried out at a section in Bukit Tungku Lembu (Figure 1) where 89 samples consist of pale to dark grey, pure calcitic laminated limestones were collected at $1 \mathrm{~m}$ interval. These samples were made into thin sections and studied under the microscope for petrographic study. The thin sections were stained using a combination of Alizarin Red S and Potassium ferricyanide, dissolved in weak hydrochloric acid as suggested by Friedman and Johnson (1992). The purpose of this staining technique is to differentiate between calcite and dolomite as well as to distinghish between ferroan and non ferroan calcites.

\section{GENERAL MICROFACIES SEQUENCE}

A detailed petrographic study based on the carbonate rock classification scheme by proposed by Dunham (1962) as well as Leighton and Pendexter (1962) has distinguished carbonate microfacies from this section including breccia (intraclastic limestone), dolomites, mudstones, wackestones, packstones, grainstones and oolitic limestone as shown in Figure 2. The overall sequence is made up of several facies cycles with each cycle shows a coarsening and shallowing upward trend starting with mudstone at the bottom and end up with brecciated limestone or more precisely can be referred to as intraclastic limestone. Each cycle however, is intercalated with zones of dolomite or dolomitic limestones especially in a zone just below the intraclastic limestone. More prominent zones of dolomite can be seen in the higher part of the section. The brecciated limestone is characterized by the presence of intraclasts cemented by calcite spar which could represent collapse breccia.

\section{DIAGENESIS}

Detailed petrographic investigations show that the limestone had experienced various diagenetic processes that took place soon after the sediments were deposited on the seafloor until deep burial. Major diagenetic processes such as micritization, dissolution, cementation, compaction and dolomitization are ubiquitous in this limestone.

\section{MICRITIZATION}

Micritization is the first diagenetic phase in formation of carbonate rocks (Adabi 2009). It takes place in the marine environment where the sediments were first deposited. In order for micritisation to happen, the sediments have to remain on the ocean floor for a period of time instead of being quickly buried. Micritization process is evident in this limestone as shown in Figure 3(e). Micrites are formed by microbes which bore small holes along the boundaries of the sediments, giving spaces for micrites to move in (Bathurst 1980). Micritization may take place continuously throughout the rock history, which will eventually destroy the original grain structure (Hashemi Azizi et al. 2013).

\section{CEMENTATION}

Cementation processes occurred almost everywhere in the coarse gained facies where four types of cements namely fibrous calcite cement, fine equant calcite cement, drusy mosaic calcite cement and medium-coarse blocky calcite cement have been identified.

\section{FIBROUS CALCITE CEMENT}

Fibrous calcite cement which appears as a rim-like fabric around the surface of the particle occurs quite frequently in this limestone. It consists of radial, needle-like or columnar, fine to medium sized calcite crystals growing outwards 


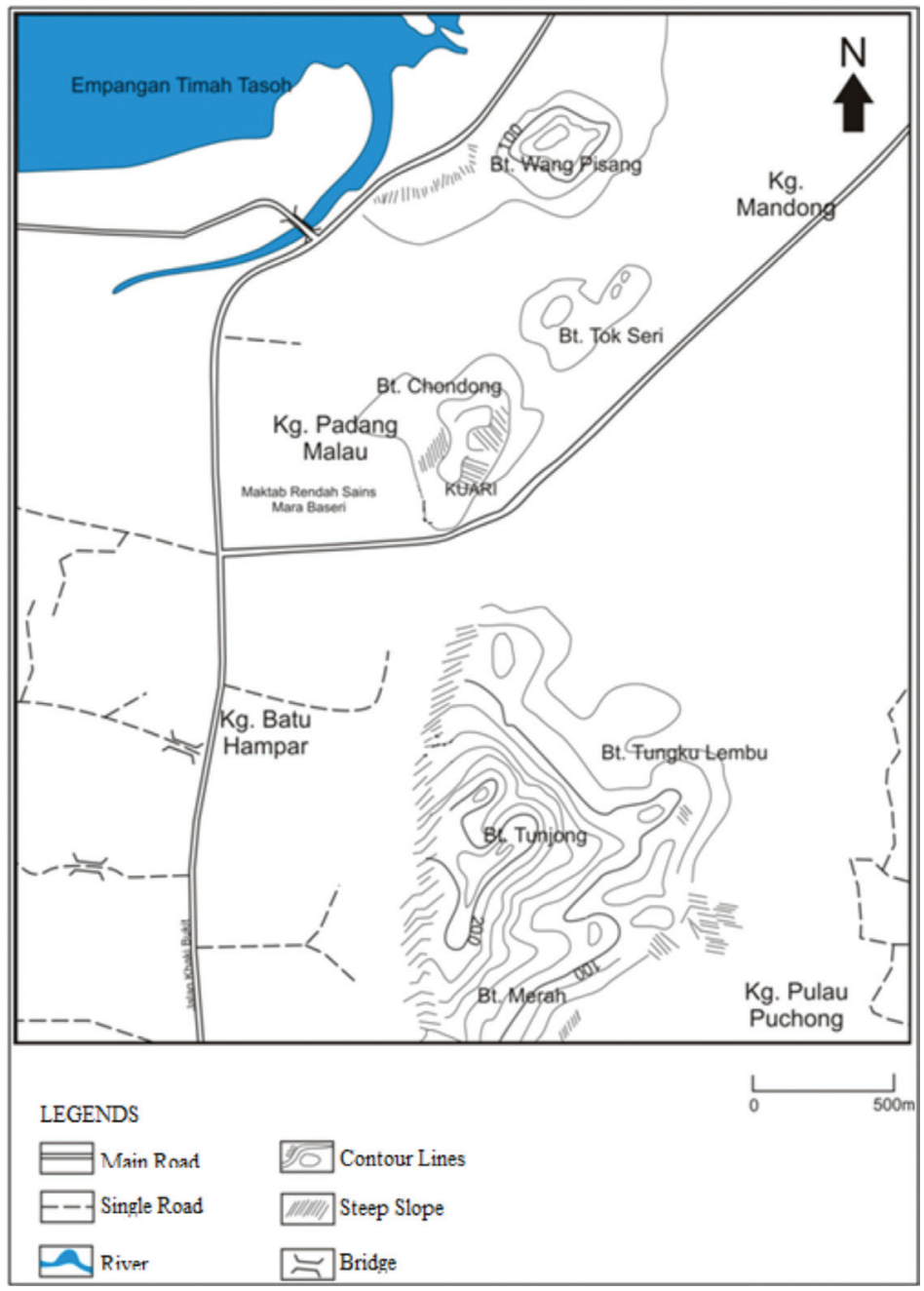

FIGURE 1. Location of Bukit Tungku Lembu in Beseri, Perlis

perpendicular to the particle's surface forming an isopachus or sub-isopachus crusts of about 20-50 $\mu \mathrm{m}$ thick (Figure $3(\mathrm{a})$ ). In some cases, the cement is only concentrated at one side of the particle and in some it appears to be undulating. Isopachus fibrous cement (Figure 3(b)) usually indicates the first generation cement formed on walls of particles as a result of early marine diagenesis precipitation (Flugel 2004; Kendall 1985). It was formed as an early stage of cementing material that turns sediments into hard rocks. The growth of fibrous rim cement formation may also be superseded by growth of other organisms such as algae during deposition or by late diagenetic cements as shown in Figure 3(c).

\section{FINE EQUANT CALCITE CEMENT}

Fine equant calcite cements are present mainly within interparticle pore spaces in the grainstones. The cement crystals are anhedral to subhedral of different sizes range from 5 to $50 \mu \mathrm{mn}$ (Figure 3(d)). This pore-filling cement may be a result of recrystallization of pre-existing cements or it could have represented granular mosaic calcite cements precipitated in a deep burial setting (Flugel 2004).

\section{DRUSY MOSAIC CALCITE CEMENT}

This type of cement shows an increasing size towards the centre of inter-particle pores. It is found precipitated inside moulds, intergranular pores and moulds of preexisting skeletal grains (Figure 3(e)). The calcite crystals are subhedral to anhedral with size ranging from 5 to 50 $\mu \mathrm{m}$. Drusy mosaic cements usually indicate a near-surface meteoric diagenesis of a later cementation stage during burial (Flugel 2004). In cases in which it fills moulds of skeletal grains, Scholle (2003) interpreted that the grains were completely dissolved, leaving voids and later were filled with sparry calcite cement. The boundaries between the grains and the matrix were distinguished by the micritic pockets preserved from the original sediment. It suggested that the sediments experienced meteoric dissolution and cementation prior to burial diagenesis. Wilkinson et al. (1985) also discovered that the increasing nature of the crystal size towards the centre of pores suggest that instead of aragonite, the cement were precipitated as calcite which normally occur in meteoric water conditions. 


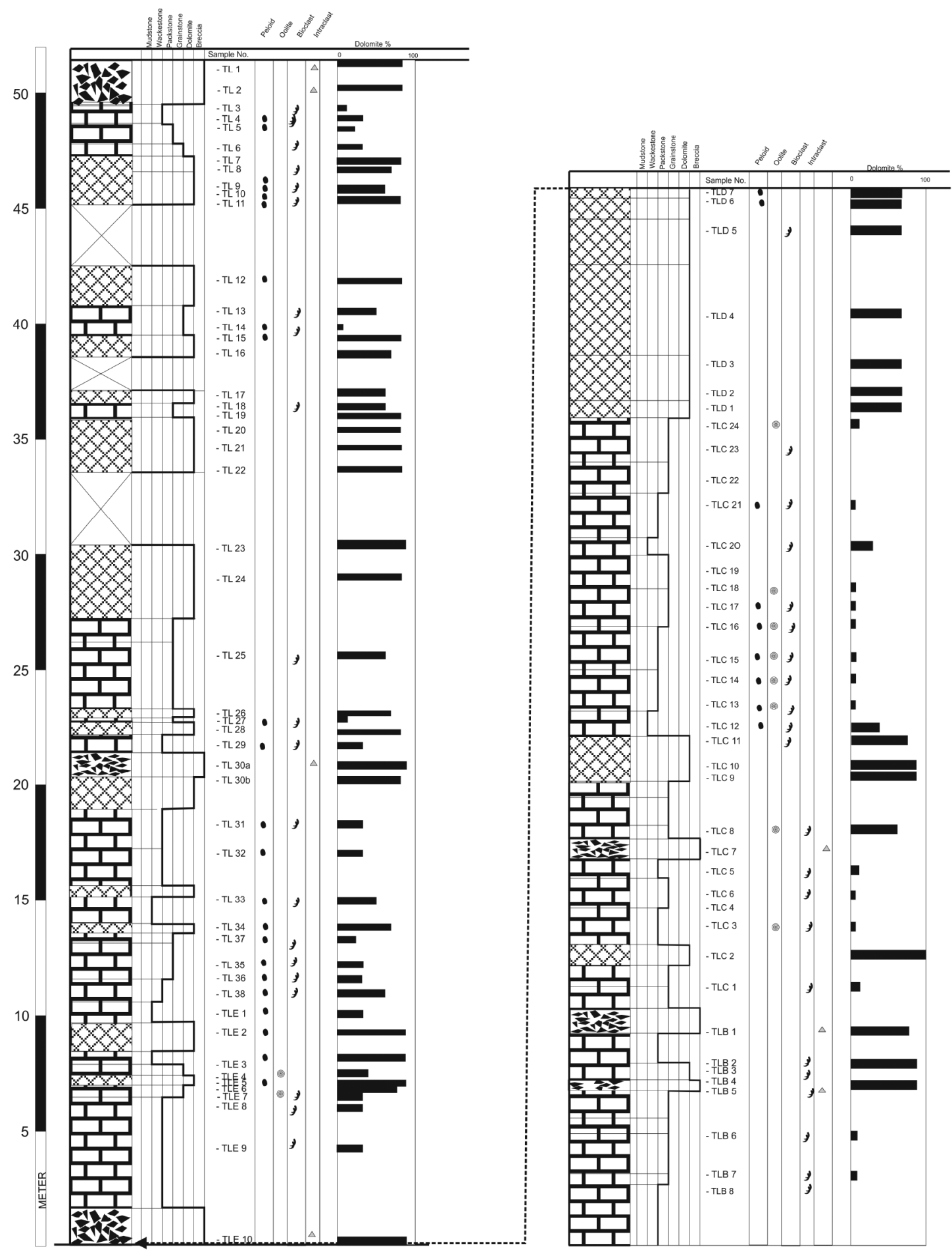

Key:

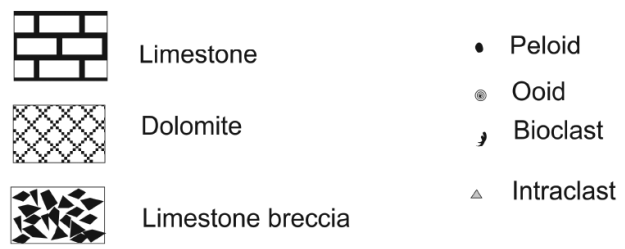

FIGURE 2. Sedimentary log showing Chuping Limestone's microfasies in Bukit Tungku Lembu 


\section{MEDIUM-COARSE GRAINED BLOCKY CALCITE CEMENT}

The medium to coarse grained cement are found in sizes more than $50 \mu \mathrm{m}$ in moulds of particles and in intergranular pores between rock fragments in breccias. It does not possess any defined shape, showing distinct boundaries between each crystal grains. They are made of non-ferroan calcite, with well-developed cleavage and extinction.

Blocky cements are typical of meteoric phreatic and burial environment as a late pore-filling stage. Mediumsized cement may also be found in mouldic pores of ooid grains. This was caused by leaching of the ooids leaving voids to be filled by calcite cements. The cements are different from intergranular cement as it is lighter in colour, granular with no distinct crystal faces and fractured. Coarser blocky calcite cements are common in brecciated facies (Figure 3(f)) which might represents collapse breccia.

\section{COMPACTION AND PRESSURE SOLUTION}

Compactions are quite dominant in Chuping Limestone as shown by fractures, broken and deformed grains, stylolites and pressure solutions. These indicate that the overburden pressure from burial had caused both mechanical and chemical compaction to occur. Mechanical compaction happened after few meters of burial (during early burial settings) causing fractures, broken and deformed grains. As the overburden pressure increase, it gives rise to closer grains packing, forming pressure solution (Halimeh et al. 2013).

\section{DOLOMITIZATION}

Dolomite occurrences are very common in Chuping Limestone of Bukit Tungku Lembu area. The dolomite occurs as individual rhomb replacing certain grains or as pervasive dolomite. The textural fabrics of dolomites in the Chuping Formation are in the forms of planar-e and planar-s. Most of them have well-cleavage, cloudy and inclusion-free. It replaces certain grains and in other cases it replaced the whole fabrics completely.

Grain-replacing dolomites made about 1 to $30 \%$ of the total rock volume, selectively replacing grains especially in ooids, pellets and skeletal allochems (Figure 4(b)). Most of them are cloudy in nature, some also possessed a clear rim in a perfect euhedral rhomb shape. Meanwhile the pervasive dolomite as shown in Figure 4(c) usually has a subhedral to anhedral texture with curvy to straight boundaries (Figure 4(d)) with well-developed cleavages.

\section{GEOCHEMISTRY}

The results of geochemical analysis of this sedimentary rock (Table 1) show big fluctuations of the elements values that may reflect the variation of subsurface water in which dolomitization had taken place. The concentrations of trace elements other than that of $\mathrm{Ca}$ and $\mathrm{Mg}$ are normally less than $1 \%$. The $\mathrm{Ca} / \mathrm{Mg}$ ratios however, are fluctuating very significantly, ranging from $1.681 \mathrm{~mol}$ to as high as
$106.942 \mathrm{~mol}$, showing that the limestones may have been precipitated from a high-Ca fluid. This data might also suggest that there are dedolomitization taking place in some of the samples in which dolomites crystal are being replaced by calcite.

$\mathrm{Fe}$ and $\mathrm{Mn}$ concentrations are fairly low suggesting that the dolomites are not of a hydrothermal origin (Zhang et al. 2009). The Mn concentration is less than $1 \mathrm{ppm}$ while Sr concentrations range from $0.008-0.031 \%$ (80-310 ppm). Meanwhile Na concentrations vary from 0.010 $0.034 \%$ (100-340 ppm) showing that the dolomites were precipitated from Na-rich fluids but with relatively low $\mathrm{Sr}$ concentration (Veizer 1983). It suggests that it is not of a marine origin as $\mathrm{Na}$ concentration in marine dolomite is normally recorded as between 110 and $160 \mathrm{ppm}$.

\section{DIAGENETIC HISTORY}

Based on the detailed petrographic study, diagenetic history of Chuping Limestone at Bukit Tungku Lembu can be summarised as follows:

\section{EARLY MARINE DIAGENESIS}

An early process of diagenesis is characterised by micritization and precipitation of early fibrous circumvoid rim cements. Micritization which normally occurs in quiet environments helps to fills pore spaces in between grains aided by microbial activities (Kim \& Lee 1996). Meanwhile, early precipitation of calcite cements acts as the first generation cement that binds sediments together. This process is assisted by water movement such as wave forcing, tidal pumping, thermal convection and diffusive transport (Scholle 2003). They transport and force water from the surface into the interior of the sediments and fill the pores between particles.

\section{METEORIC ENVIRONMENT}

Meteoric environment can be divided into phreatic (saturated) and vadose (unsaturated) zones (Flugel 2004; Scholle 2003). A vadose zone is located nearest to the surface of the earth, overlies the phreatic zone. Here, dissolution of carbonate materials is common and the cement fabrics usually reflect the way how water was distributed through the particles. It includes formation of pendant-like cement, meniscus cement in between grains, whisker crystals, microspar and some other features (Scholle 2003). Figure 3(c) shows pendant cements in grainstone. A phreatic zone occurs below water table where the pore spaces are completely filled with freshwater (Flugel 2004). In this zone, intrgranular, mouldic and vuggy porosities are recemented by calcite. Figure 4(a) shows formation of mouldic vugs in ooids, destroying the internal structures of ooids completely and replaced it with medium grained granular calcite cement. It is also shown by the complete precipitation of equant calcite in intergranular pore spaces (Figure 3(a)). 
TABLE 1. XRF data of different elements from selected samples of Chuping limestones

\begin{tabular}{|c|c|c|c|c|c|c|c|c|c|c|c|c|}
\hline $\begin{array}{l}\text { Sample/ } \\
\text { Conc. }\end{array}$ & $\begin{array}{l}\mathrm{CaO} \\
(\%)\end{array}$ & $\begin{array}{c}\mathrm{MgO} \\
(\%)\end{array}$ & $\begin{array}{c}\mathrm{Al}_{2} \mathrm{O}_{3} \\
(\%)\end{array}$ & $\begin{array}{c}\mathrm{Fe}_{2} \mathrm{O}_{3} \\
(\%)\end{array}$ & $\begin{array}{l}\mathrm{K}_{2} \mathrm{O} \\
(\%)\end{array}$ & $\begin{array}{c}\mathrm{MnO} \\
(\%)\end{array}$ & $\begin{array}{c}\mathrm{Na}_{2} \mathrm{O} \\
(\%)\end{array}$ & $\begin{array}{l}\mathrm{P}_{2} \mathrm{O}_{5} \\
(\%)\end{array}$ & $\begin{array}{l}\mathrm{SiO}_{2} \\
(\%)\end{array}$ & $\begin{array}{l}\mathrm{SrO} \\
(\%)\end{array}$ & $\begin{array}{l}\mathrm{TiO}_{2} \\
(\%)\end{array}$ & $\begin{array}{c}\mathrm{Ca} / \mathrm{Mg} \\
(\mathrm{mol})\end{array}$ \\
\hline TL4 & 40.263 & 9.635 & 0.266 & 0.051 & 0.014 & 0.005 & 0.021 & 0.004 & 0.354 & 0.010 & 0.009 & 4.179 \\
\hline TL6 & 44.292 & 4.321 & 0.161 & 0.029 & 0.012 & 0.006 & 0.014 & 0.005 & 0.200 & 0.009 & 0.008 & 10.250 \\
\hline TL7 & 37.587 & 13.197 & 0.147 & 0.092 & 0.014 & 0.005 & 0.027 & 0.003 & 0.302 & 0.010 & 0.012 & 2.848 \\
\hline TL12 & 43.870 & 5.117 & 0.341 & 0.065 & 0.018 & 0.007 & 0.016 & 0.005 & 0.414 & 0.010 & 0.011 & 8.573 \\
\hline TL15 & 40.207 & 10.265 & 0.066 & 0.039 & 0.012 & 0.005 & 0.022 & 0.005 & 0.112 & 0.010 & 0.008 & 3.917 \\
\hline TL20 & 35.445 & 16.552 & 0.079 & 0.037 & 0.010 & 0.004 & 0.029 & 0.003 & 0.094 & 0.011 & 0.009 & 2.141 \\
\hline TL22 & 41.898 & 7.805 & 0.082 & 0.047 & 0.014 & 0.005 & 0.018 & 0.004 & 0.126 & 0.010 & 0.008 & 5.368 \\
\hline TL23 & 40.940 & 9.011 & 0.092 & 0.037 & 0.013 & 0.004 & 0.020 & 0.006 & 0.204 & 0.010 & 0.008 & 4.543 \\
\hline TL26 & 34.121 & 17.724 & 0.089 & 0.049 & 0.012 & 0.008 & 0.033 & 0.004 & 0.147 & 0.012 & 0.009 & 1.925 \\
\hline TL28 & 46.800 & 1.449 & 0.083 & 0.028 & 0.014 & 0.005 & 0.011 & 0.004 & 0.134 & 0.010 & 0.008 & 32.298 \\
\hline TL29 & 43.785 & 5.610 & 0.062 & 0.040 & 0.012 & 0.005 & 0.015 & 0.005 & 0.111 & 0.008 & 0.008 & 7.805 \\
\hline TL33 & 42.771 & 6.903 & 0.095 & 0.026 & 0.010 & 0.004 & 0.018 & 0.005 & 0.115 & 0.008 & 0.008 & 6.196 \\
\hline TL37 & 44.433 & 4.441 & 0.046 & 0.030 & 0.011 & 0.004 & 0.015 & 0.010 & 0.073 & 0.009 & 0.007 & 10.005 \\
\hline TLB5 & 47.589 & 0.445 & 0.061 & 0.018 & 0.010 & 0.004 & 0.010 & 0.004 & 0.077 & 0.021 & 0.007 & 106.942 \\
\hline TLB8 & 47.476 & 0.535 & 0.050 & 0.024 & 0.010 & 0.004 & 0.010 & 0.004 & 0.078 & 0.010 & 0.007 & 88.740 \\
\hline TLC1 & 47.166 & 0.950 & 0.071 & 0.026 & 0.011 & 0.003 & 0.011 & 0.004 & 0.086 & 0.035 & 0.007 & 49.648 \\
\hline TLC2 & 33.980 & 18.382 & 0.044 & 0.030 & 0.010 & 0.005 & 0.034 & 0.005 & 0.052 & 0.011 & 0.008 & 1.849 \\
\hline TLC3 & 47.279 & 0.655 & 0.035 & 0.017 & 0.010 & 0.004 & 0.010 & 0.006 & 0.054 & 0.025 & 0.007 & 72.182 \\
\hline TLC5 & 47.251 & 1.016 & 0.173 & 0.021 & 0.010 & 0.003 & 0.011 & 0.004 & 0.192 & 0.015 & 0.007 & 46.507 \\
\hline TLC6 & 47.251 & 0.889 & 0.202 & 0.025 & 0.011 & 0.003 & 0.010 & 0.004 & 0.221 & 0.018 & 0.007 & 53.151 \\
\hline TLC9 & 34.318 & 17.107 & 0.144 & 0.053 & 0.013 & 0.006 & 0.030 & 0.004 & 0.148 & 0.011 & 0.010 & 2.006 \\
\hline TLC18 & 47.364 & 0.464 & 0.046 & 0.018 & 0.011 & 0.005 & 0.010 & 0.004 & 0.063 & 0.028 & 0.007 & 102.078 \\
\hline TLC21 & 47.279 & 0.546 & 0.248 & 0.021 & 0.012 & 0.004 & 0.011 & 0.004 & 0.260 & 0.031 & 0.008 & 86.592 \\
\hline TLC24 & 46.406 & 1.911 & 0.059 & 0.033 & 0.013 & 0.004 & 0.011 & 0.004 & 0.084 & 0.012 & 0.007 & 24.284 \\
\hline TLD1 & 33.642 & 18.181 & 0.153 & 0.063 & 0.011 & 0.006 & 0.033 & 0.007 & 0.217 & 0.011 & 0.010 & 1.850 \\
\hline TLD4 & 33.501 & 18.431 & 0.088 & 0.065 & 0.011 & 0.005 & 0.032 & 0.004 & 0.105 & 0.011 & 0.011 & 1.818 \\
\hline TLD5 & 32.853 & 19.547 & 0.038 & 0.054 & 0.010 & 0.006 & 0.033 & 0.004 & 0.045 & 0.011 & 0.009 & 1.681 \\
\hline TLE1 & 43.842 & 5.250 & 0.068 & 0.034 & 0.014 & 0.004 & 0.016 & 0.007 & 0.136 & 0.010 & 0.009 & 8.351 \\
\hline TLE4 & 44.631 & 4.303 & 0.047 & 0.030 & 0.012 & 0.004 & 0.014 & 0.007 & 0.083 & 0.010 & 0.008 & 10.372 \\
\hline TLE6 & 42.010 & 7.590 & 0.047 & 0.031 & 0.011 & 0.005 & 0.020 & 0.006 & 0.109 & 0.011 & 0.008 & 5355. \\
\hline
\end{tabular}

EARLY TO LATE BURIAL DIAGENESIS

Burial diagenesis took place in the subsurface, shown by evidence of physical alteration such as compaction, pressure solution (existence of stylolites) and late stage cementation (Flugel 2004). Evidents of burial diagenesis are shown by the presence of medium to coarse, blocky, sparry calcite cements as well as broken fragments of allochems. Late stage dolomitization is another indication of burial diagenesis. Petrographic studies of this limestone show that most of the dolomite crystals are of medium to coarse crystal size, light to dark brown in colour. Individual rhombus dolomite crystals that are not affected by any compaction or pressure indicate a replacement by dolomite crystal growth in a shallow burial environment. However, dolomites that are tightly packed showing xenotopic texture suggested a late stage burial environment in which the rock experienced compaction. This is also supported by the presence of saddle dolomite. There is also an indication of a possible dedolomitization process occurred in the Chuping Limestone. Referring to the petrophysical and geochemical data of TL12, the high $\mathrm{Ca} / \mathrm{Mg}$ ratio does not reflects the $80 \%$ dolomite crystal observed in the thin section. It is believed that the dolomite crystals have been replaced by calcite at a very late stage.

\section{PARADIAGENETIC SEQUENCE}

Petrographic evidences show that the first generation cement appeared in the form of fibrous rimmed cement 

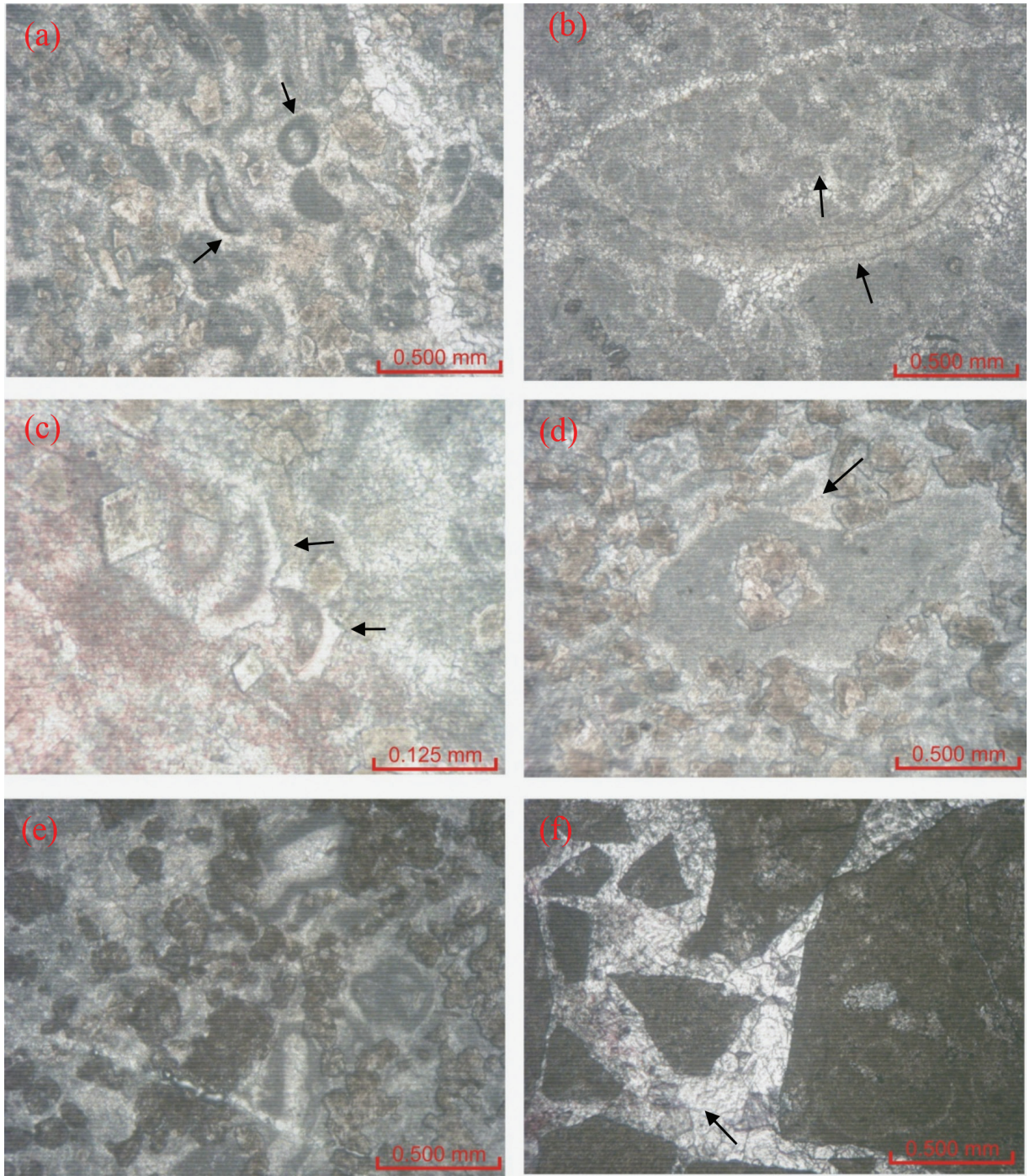

FIGURE 3. (a) Showing fibrous rim cements, (b) Fibrous rim cement on the surface of a brachiopod clast,

(c) Growth of pendant cements indicating a vadose meteoric environment, (d) inter-granular fine equant calcite cement

(e) Drusy mosiac calcite cement and (f) Medium to coarse grained blocky calcite cement with micritic pockets

on the surface of allochems. Its formation is assisted by water movement and also from secretions of bacteria and other multicellular organism in the earlier marine diagenesis. This binds the sediments together and formed a hard rock. This is followed by dissolution of allochems and recrystallisation forming secondary calcite spar cements that fills the pores in between the sediments. This happened in the meteoric environment in which dissolution is most possible. Then a series of physical and chemical compaction takes place as the sediments entered burial diagenetic phase. Stylolites, pressure solution and deformation of clasts occur due to the pressure. Dolomitisation serves as the final diagenetic process as it replaces matrix and molds of skeletal clasts with euhedral to subhedral dolomites crystals. Table 2 shows a paradiagenetic sequence which consisted of the various diagenetic processes experienced by the Chuping Limestone in their approximate order of occurrence.

\section{CONCLUSION}

These diagenetic processes play a really important role in the history of the Chuping Limestones, Overall the Chuping Limestone had undergone 3 diagenetic processes. It started with early marine diagenesis which is indicated by the process of micritization and formation of fibrous rim calcite cements. Marine phreatic environment then took place in shallow marine water involving the stabilizing of metastable minerals into stable calcite cements. Then the sediment came into a meteoric phreatic environment in which voids and pore spaces created by dissolution were recemented. This is followed by diagenesis in the subsurface environments where mechanical compaction took place after few meters of burial forming fractures, deformation and destruction of grain structures. As the overburden pressure increases, dissolution occurs forming pressure solutions, stylolites as well as new cement generations. Replacement by 

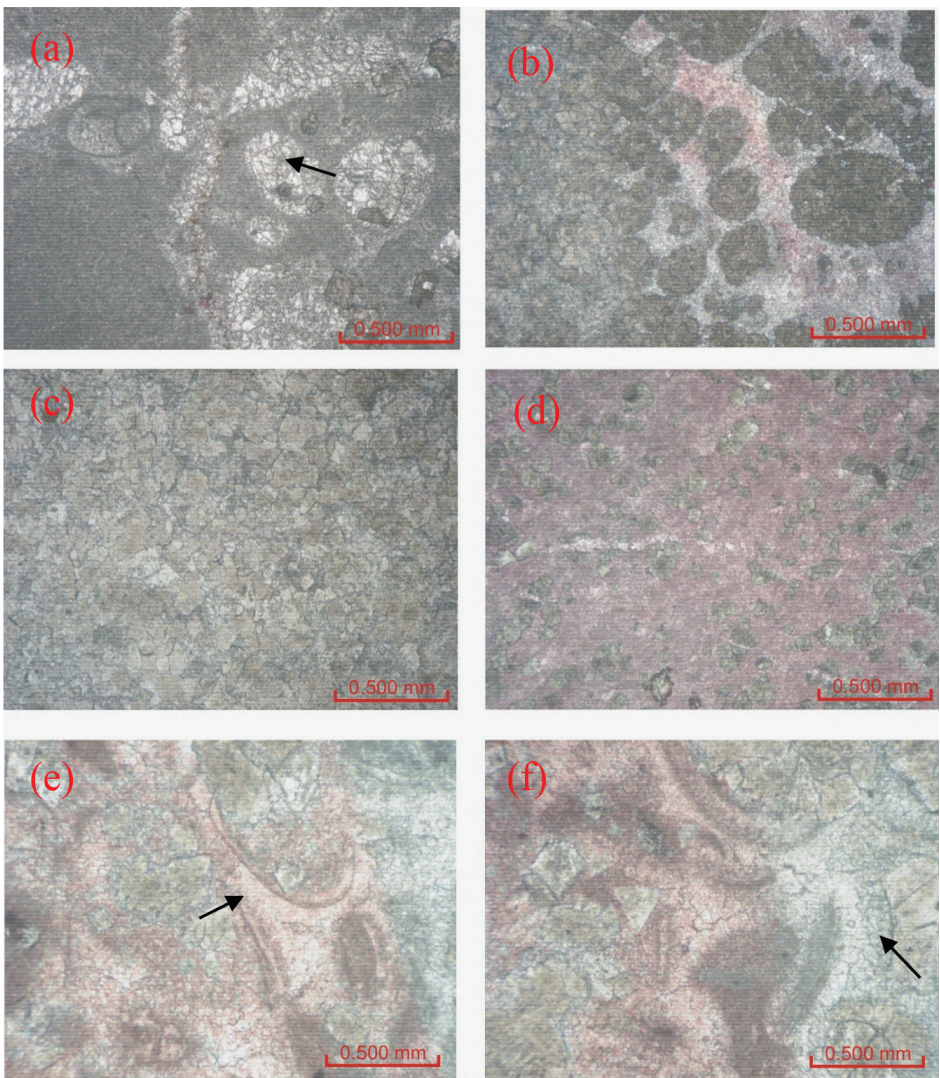

FIGURE 4. (a) Mouldic voids formed through leaching and dissolution in a meteoric phreatic environment,

(b) Dolomitization happened as replacement in ooids grains, (c) Complete dolomitization, (d) Partially dolomitized, the stained in red are calcite while the unstained minerals are dolomites, (e) and (f) showing the occurrence of first (indicated by the arrow) and second generation cement (in the box)

TABLE 2. Paradiagenetic sequence of Chuping Formation

\begin{tabular}{|c|c|c|c|c|}
\hline & $\begin{array}{c}\text { Early marine } \\
\text { diagenesis }\end{array}$ & $\begin{array}{c}\text { Meteoric } \\
\text { diagenesis }\end{array}$ & $\begin{array}{c}\text { Shallow } \\
\text { burial }\end{array}$ & $\begin{array}{l}\text { Late burial } \\
\text { diagenesis }\end{array}$ \\
\hline Marine cementation & & & & \\
\hline Micritization & & & & \\
\hline Dissolution & & & & \\
\hline Meteoric cementation & & & & \\
\hline Compaction & & & & \\
\hline Late stage cementation & & & & \\
\hline Stylolitization & & & & \\
\hline Dolomitization & & & & \\
\hline
\end{tabular}

dolomites follows and re-changed the whole limestone fabrics and structures.

\section{ACKNOWLEDGEMENTS}

This study is supported by the FRGS/2/2014/STWN06/ UKM/1/1 (Kesesuaian Tapak Warisan geologi dan Landskap untuk Pembangunan lestari Wilayah di Barat Laut Semenanjung Malaysia) grant.

\section{REFERENCES}

Adabi, M. 2009. Multistage dolomitization of upper Jurassic Mozduran Formation, Kopet Dagh Basin, N.E. Iran. Carbonates Evaporites 24: 16-32.

Azimah binti Hussin. 1998. Pengaruh litologi dan geokimia ke atas kualiti kapur daripada batu kapur Formasi Chuping, Perlis. Tesis Sarjana Sains. Universiti Kebangsaan Malaysia (Unpublished). 
Bathurst, R.G.C. 1980. Stromatactis origin related to submarine-cemented crust in Paleozoic mudmounds. Geology 8: 131-134.

Bathurst, R.G.C. 1971. Carbonate Sediments and Their Diagenesis. Netherlands: Elsevier Publishing Company. p. 415.

Castanier, S., Le Metayer-Levrel, G. \& Perthuisot, J.P. 1999. $\mathrm{Ca}$-carbonates precipitation and limestone genesis- the microbiogeologist point of view. Sedimentary Geology 126(1-4): 9-23.

Dunham, R.J. 1962. Classification of carbonates rocks according to depositional texture. American Ass. of Petroleum Geo. 43: $1-38$

Flugel, E. 2004. Microfacies of Carbonate Rocks. Germany: Springer. p. 996.

Fontaine, H., Chonglakmani, C., Ibrahim Bin Aman \& Piyasin, S. 1994. A well-defined Permian biegeographic unit: Peninsular Thailand and Northwest Peninsular Malaysia. Journal of Southeast Asian Earth Sciences 9(1/2): 129-151.

Fontaine, H., Khoo, H.P. \& Vachard, D. 1988. Discovery of triassic fossils at Bukit Chuping, in Gunung Sinyum area and at Kota Jin, Peninsular Malaysia. Journal of Southeast Asian Earth Sciences 2(3/4): 145-162.

Friedman, G.M. \& Johnson, K.G. 1992.Exercise in Sedimentology. Tulsa. Oil and Gas Consultant International Inc. p. 208.

Gobbett, D.J. \& Hutchison, C.S. 1973. Geology of The Malay Peninsula. New York: John Wiley \& Sons, Inc. p. 438.

Hashemi Azizi, H.S., Mirab Shabestari, G. \& Khazaei, A. 2013. Petrography and geochemistry of PaleoceneEocene limestones in the Ching-dar syncline, Eastern Iran. Geoscience Frontiers 5(3): 429-438.

Jones, C.R. 1962. Progress Report on Geological Work in Upper Perak and The Langkawi Islands. Prof. Paper Geol. Survey Dept. Fed. Malaya. E-63. 2-G. pp. 11-12.

Jones, C.R. 1981. The geology and mineral resources of Perlis, North Kedah and the Langkawi Islands. Geological Survey of Malaysia Memoir 17: 1-257.

Kendall, A.C. 1985. Radiaxial fibrous calcite: A reappraisal. In Carbonate Cements, edited by Schneidermann, N. \& Harris, P.M. Spec. Publ. Soc. Econ. Paleontol. Mineral. 36: 59-77.

Kim, J.C. \& Lee, Y.I. 1996. Marine diagenesis of lower Ordovician carbonate sediments (Dumugol Formation), Korea: Cementation in Calcite Sea. Sedimentary Geology 105: 241-257.

Kobayashi, T. \& Tamura, M. 1968. Myophoria (s.1.) in Malaya in a note on the Triassic Trigoniacea. In Geology of Palaentology of Southeast Asia. Tokyo: Univ. of Tokyo Press. 88-137.
Leighton, M.W. \& Pendexter, C. 1962. Carbonate Rock Types I. In Classification of Carbonate Rocks: A Symposium, edited by Ham, W.E. Tulsa, Oklahoma: The American Association of Petroleum Geologists. AAPG Memoir 1. pp. 33-61.

Moore, C.H. 1989. Carbonate Diagenesis and Porosity. Netherlands: Elsevier Science Publisher B.V. p. 338.

Rao, C.P. 1988. Paleoclimate of some Permo-Triassic carbonates of Malaysia. Sedimentary Geology 60: 163-171.

Scholle, P.A. \& Ulmer-Scholle, D.S. 2003. A Color Guide to the Petrography of Carbonate Rocks: Grains, Textures, Porosity, Diagenesis. Tulsa, Oklahoma: The American Association of Petroleum Geologists. AAPG Memoir 77. p. 459.

Tucker, M.E. \& Wright, V.P. 1990. Carbonate Sedimentology. Oxford: Blackwell Publishing. p. 482.

Veizer, J. 1983. Chemical diagenesis of carbonates: theory and application of trace element technique. In Stable Isotopes in Sedimentary Geology, edited by Arthur, M.A., Anderson, T.F., Kaplan, I.R., Veizer, J. \& Land, L.S. Soc. Econ. Paleont. Miner. Short Course No. 10, 3.1 -3.100.

Wayne, M.A. 2008. Geology of Carbonate Reservoirs: The Identification, Description, and Characterization of Hydrocarbon Reservoirs in Carbonate Rocks. New Jersey: John Wiley \& Sons Inc. p. 144.

Wilkinson, B.H., Smith, A.L. \& Lohman, K.C. 1985. Sparry calcite marine cement in upper Jurassic limestone of South Eastern Wyoming. In Carbonate Cements, edited by Schneidermann, N. \& Harris, P.M. Spec. Publ. Soc. Econ. Paleontol. Mineral. 36: 169-184.

Zhang, J., Hu, W., Qian, Y., Wang, X., Cao, J., Zhu, J., Li, Q. \& Xie, X. 2009. Formation of saddle dolomites in Upper Cambrian carbonates, western Tarim Basin (northwest China): Implications of fault-related fluid flow. Marine and Petroleum Geology 26(8): 1428-1440.

Geology Programme

Faculty of Science and Technology

Universiti Kebangsaan Malaysia

43600 UKM Bangi, Selangor Darul Ehsan

Malaysia

*Corresponding author; email: che@ukm.edu.my

Received: 29 June 2016

Accepted: 11 November 2016 